\title{
Eco -friendly Flame Retardant Via Self Assembly Coating
}

\author{
E. A. El-Alfy ${ }^{1}$ A. A. Younis ${ }^{2 *}$ S. H. Samaha ${ }^{2}$ and A. M. Salama ${ }^{3}$ \\ ${ }^{1}$ Textile Division, National Research Centre, Dokki, ${ }^{2}$ National Institute for Standard \\ (NIS) P.O Box: 136 Giza, Code No. 12211, Tersa St, Alharam, Giza and ${ }^{3}$ Faculty of \\ Science, Zagazig University, Egypt
}

\begin{abstract}
$\mathbf{L}$ IMITING oxygen index (LOI) of the most of the textiles in use is lower than $21 \%$, while cotton has $18.4 \%$, which means that they can burn easily once the fire has started. Currently, there is some difficulty in making durable flame retardant (DFR) treatments for cotton fabric using an ordinary one step wet process, which is nontoxic to humans and the environment. This research has also aimed to investigate the optimum treatment conditions that allow controlled deposition of zinc oxide onto carboxymethylated cotton fabric using sodium hypophosphite (SHP) /citric acid (CA). In this regard, the influence of the process parameters on the physicochemical and performance properties of treated cotton fabric will elucidate. The treated fabric was monitored for carboxylic content, LOI, char length, char residue, whiteness index, retained tensile strength and elongation at break. The formation of zinc oxide was verified using UV-Visible spectrum at wavelength of $325 \mathrm{~nm}$. Also, the zinc oxide in nano scale was monitored and observed in the range of $19-41 \mathrm{~nm}$ by transition electron microscope (TEM). The treated cotton fabrics show LOI value and char length $25.3 \%, 3 \mathrm{~cm}$, respectively, compared with 18.4 and $11 \mathrm{~cm}$ for untreated fabric. The existence of zinc oxide particle interaction and other functional groups introduced into cotton fabrics were promoted by Fourier transform infrared spectroscopy (FTIR), scanning electron microscope (SEM) and X-ray diffraction (XRD).
\end{abstract}

Keywords: Carboxymethylation, Cotton fabrics, Functional finishing, Flame retardant, LOI.

\section{Introduction}

In the last years, nanotechnology has attracted a great interest from both industrial and academic research, because of the encouraging and astonishing results achieved in numerous fields by employing nano-sized objects. There are different methods to enhance final properties of fibers and fabrics in particular, smart textiles displaying antimicrobial or UV radiation protection [1], dye fastness, wrinkle resistance finishing, superhydrophobicity and photocatalytic properties [2-5]. At the present time, researchers focus on protecting the textile fabrics from ignition by using zinc oxide, titanium dioxide, phosphoric acid [68], behind surface modification after-treatments capable of changing or conferring different properties to the investigated textiles. The curing step has to be applied without any effect on the properties of the textile. For that, the surface has to be modified by formation of micro-to nano-sized coatings and synthesis novel coatings for fabrics and fibers. These coatings described by Layer by
Layer (LbL) which exhibit hybrid organic and inorganic composition or complete inorganic, can be made by using different approaches [9]. LbL was first described in 1966 [10-14]. The LbL is an encouraging technique by which an adsorption technique of nano-particles is created [10]. Simply, it is recognized as step-by-step film build-up based on electrostatic connections for polyanion/ polycation couples to form polyelectrolyte multilayers [15]. This will be a good environment for the inorganic nanoparticles to demonstrate different connections (such as; hydrogen bonds, covalent bonds, etc.) next to the electrostatic one. Application of the LbL concept for fabric treatment of an electrostatic connection requires the alternate immersion of the fabric into an oppositely charged polyelectrolyte usually water-based solution or dispersion. As a result, the occurrence of positively and negatively charged layers piled up on the substrate surface, exploiting a complete surface charge reversal after every immersion step [16]. Recently, many articles, including the main role of $\mathrm{LbL}$ in the protection of fibers and fabrics from

*Corresponding Author: Email: dr_ahmedabdee@yahoo.com, Mobile: +201152526422

DOI : 10.21608/ejchem.2017.768.1024

C2017 National Information and Documentation Center (NIDOC) 
the ignition and the aim of synthesis a thermal insulator system $[9,17]$. Such barrier may operate as a thermal shield for the surrounding substrate, favoring such phenomena as char formation and inhibiting the production of volatile species that can increase the combustion (as; cellulose). Certainly, a thermal insulator barrier can support the dehydration of cellulose followed with char formation and inhibit its depolymerization toward the production of volatile species as furan and levoglucosan [18].

\section{Materials and Methods}

\section{Materials}

Gray Loomstate cotton fabric (100\%, cover factor $=12.5$ ), plain weave 1/1,3/1 (Warp-way: $3 / 1$ warp way twill) of weight $265 \mathrm{~g} / \mathrm{m}^{2}$ was supplied by the Misr Company for Spinning and Weaving, El Mehala El-Kobra, Egypt. Monochloroacetic acid (MCAA, $\mathrm{C}_{2} \mathrm{H}_{3} \mathrm{ClO}_{2}, 99 \%$ ), citric acid (99\%), and sodium hypophosphite were supplied from Sigma-Aldrich Company. Sodium hydroxide, sodium carbonate, sodium silicate, hydrogen peroxide (30\%), orthophosphoric acid (85\%), Egyptol $^{\circledR}$ (non-ionic wetting agent based on ethylene oxide condensate), and methanol were supplied by El Gomhoria Company, Cairo, Egypt.

\section{Desizing and scouring}

The cotton fabric was desized and scoured by using an aqueous solution containing sodium hydroxide (6 \%), Egyptol (2 g/l), liquor to goods ratio of $50: 1$ at $95^{\circ} \mathrm{C}$ for $30 \mathrm{~min}$. After scouring, the specimens were washed thoroughly with water then dried at ambient temperature.

\section{Bleaching}

Scoured cotton fabric was treated with an aqueous solution of hydrogen peroxide $(6 \mathrm{~g} / \mathrm{L})$, sodium silicate $(2 \mathrm{~g} / \mathrm{L})$ and organic stabilizer (1 $\mathrm{g} / \mathrm{L})$, at $\mathrm{pH} 10.5$ using aqueous sodium hydroxide. The liquor to goods ratio was 50:1 and the bleaching process was carried out at $95^{\circ} \mathrm{C}$ for 45 min. The fabric was washed with water at $100^{\circ} \mathrm{C}$ for several times ( 5 times) followed by washing with running cold water before drying at ambient temperature.

\section{Preparation of nano zinc oxide}

Nano zinc oxide was synthesized by sol-gel technique [19.20]. Unless otherwise stated before, the method was performed as follows: 0.01 mole of zinc acetate dihydrate was dissolved in $50 \mathrm{ml}$ methanol and heated at $50^{\circ} \mathrm{C}$ along with stirring for $1 \mathrm{hr}$, thus making the precursor solution A. Solution B was prepared by dissolving 0.02 mole sodium hydroxide in $50 \mathrm{ml}$ of methanol then heated at $50{ }^{\circ} \mathrm{C}$ with continuous stirring for $1 \mathrm{hr}$. The $\mathrm{ZnO}$ nano-sol was synthesized firstly, by adding solution B into solution A with a dropwise, constant stirring at $50^{\circ} \mathrm{C}$ for $30 \mathrm{~min}$, then the mixture kept stirring for $2 \mathrm{hr}$ and cooled at room temperature. Subsequently, a homogenous and transparent sol was obtained. Finally, the precipitate was dried in an oven (TARKO 200) at $85^{\circ} \mathrm{C}$ for $4 \mathrm{hr}$ and thermally treated at $450^{\circ} \mathrm{C}$ for $3 \mathrm{hr}$ to form nano zinc oxide.

\section{Treatment of carboxymethylated cotton nano} zinc oxide

Carboxymethylated cotton fabric (CMC) having a carboxyl content of $335 \mathrm{meq} / 100$ gm [21 ] was padded in an aqueous solution containing different concentrations of nano zinc oxide (3-6\%), citric acid (3-7\%) and sodium hypophosphite $(4-7 \%)$. The treated fabric was dried at $85^{\circ} \mathrm{C}$ for $5 \mathrm{~min}$ and cured at different temperatures $\left(150-180^{\circ} \mathrm{C}\right)$ for varied time intervals (1-7min).

\section{Testing and analysis}

Determination of limiting oxygen index (LOI) The determination of the lowest oxygen percentage need to ignite continues was carried out using an LOI instrument (Rheometric Scientific LTD, UK) according to standard test method, ISO 4589 [22]. The specimen (5 specimens) of cotton fabrics with dimension $5 \times 15 \mathrm{~cm} 2$ was handled in $U$ holder in a vertical position inside a thermal glass chamber. Both of oxygen (ignition gas) and nitrogen (as purification for oxygen gas from mixing with other gasses and lose its characteristics) gasses were used to ignite the specimen. Flame source was propane gas.

\section{Char length}

The char length was measured according to BS 3119 standard method [23].

\section{Char residue}

The weight loss of each specimen has been measured [24] by dividing W2 by W1 according to the following equation :

$$
\text { Char yield }(\%)=\mathrm{W}_{2} / \mathrm{W}_{1} \times 100
$$

where $\mathrm{W}_{1}$ and $\mathrm{W}_{2}$ are the weight of specimens 
before and after burning, respectively.

Tensile strength and elongation at break

The mechanical properties of the uncoated and coated specimens were tested on the Shimadzu Universal Tester of (CRT)- type S-500, Japan, according to ASTM D5035 [25]. Each specimen was cut in a warp direction with dimension $3.5 \times 15 \mathrm{~cm}^{2}$. The average of the five specimens results is considered.

\section{Whiteness index}

The whiteness of the specimens before and after coating was measured by the UltraScan@ Pro Hunter lab spectrophotometer according to standard test method [26].

\section{FTIR analysis}

FTIR spectra were recorded using Nicolet 380 Spectrometer-USA, depending on the absorption of electromagnetic radiation in the frequency range 4000 to $400 \mathrm{~cm}^{-1}$, with an average of 32 scans by using a resolution of $4 \mathrm{~cm}^{-1}$. A pressure of $18 \mathrm{Kpa}$ was derived to the crystal holder to make reproducible contact between the crystal face and the fabric. [27,28].

\section{Transition electron microscope (TEM)}

The Tecnai F12 TEM (Philips Electron Optics, Holland) was used to measure the zinc oxide nanoparticle size. Grid with size $97 \mu \mathrm{m}$ was used to prepare the test specimen by dropping 2 to 3 drops of zinc oxide nanoparticles on a 200 mesh formvar coated copper (grid size: $97 \mu \mathrm{m}$ ) (Ted Pella, Inc., Redding, CA, USA), then the excess solution was removed before drying for $12 \mathrm{hr}$ to image particles.

\section{Scanning electron microscope (SEM)}

JEOL JSM-840A (Tokyo, Japan) scanning microscope at an accelerating voltage of $15 \mathrm{kV}$ was used to study the surface morphology of cotton fabrics and zinc oxide nanoparticles loaded cotton fabrics.

\section{UV-Visible spectrophotometry}

The UV-visible spectra of $\mathrm{ZnO}$ suspended in deionized water were recorded in Specord 50 ANALYTIKJENA $^{\circledR}$ spectrophotometer, from 200-800nm, then measured after sonication.

$X R D$ analysis

$\mathrm{X}$-ray diffraction was used to analysis the specimens by using Phillips ${ }^{\circledR P W} 1710$ X-Ray
Diffractometer. The instrument including nickelfiltered $\operatorname{CuK\alpha }(\lambda=1.54 \AA)$. The diffracted intensities and radiation were recorded from 30 $80^{\circ} 2 \theta$ angles [29].

\section{Results and Discussion}

Characterization of the prepared zinc oxide nano particles ( $\mathrm{ZnO} \mathrm{NPs})$

\section{Fourier transform infrared}

The FTIR spectrum of carboxymetylated treated fabrics is shown in Fig. 1, compound A. In addition to the cellulose peaks at new peaks indicate the presence of the following: carboxylic group: $3531 \mathrm{~cm}^{-1}$ (carboxylic O-H stretching); $1653 \mathrm{~cm}^{-1}(-\mathrm{C}=\mathrm{O}$ stretching of carboxylic acid); $1120 \mathrm{~cm}^{-1}$ (-C-O-C-asymmetric bridge stretching), $701 \mathrm{~cm}^{-1}(-\mathrm{O}-\mathrm{C}=\mathrm{O}$ bending in carboxylic acid) [21]. The FTIR spectrum of carboxymethlyated specimens treated with nano zinc oxide as shown in Fig. 1 compound B shows different absorbance peaks: $3880 \mathrm{~cm}^{-1}\left(\mathrm{O}-\mathrm{H}\right.$ free); $3349 \mathrm{~cm}^{-1}(\mathrm{O}-\mathrm{H})$;

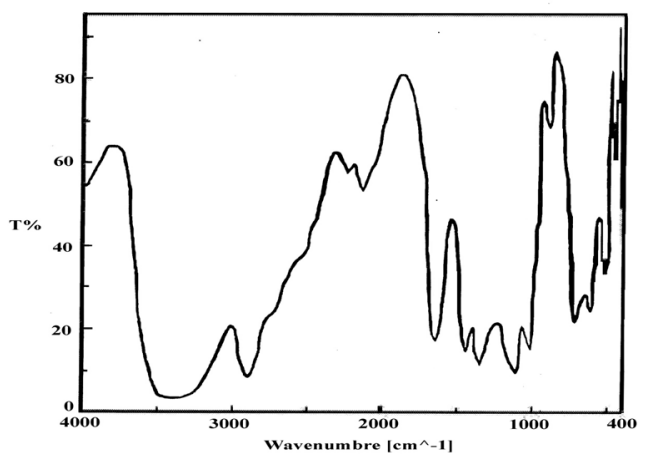

Compound A

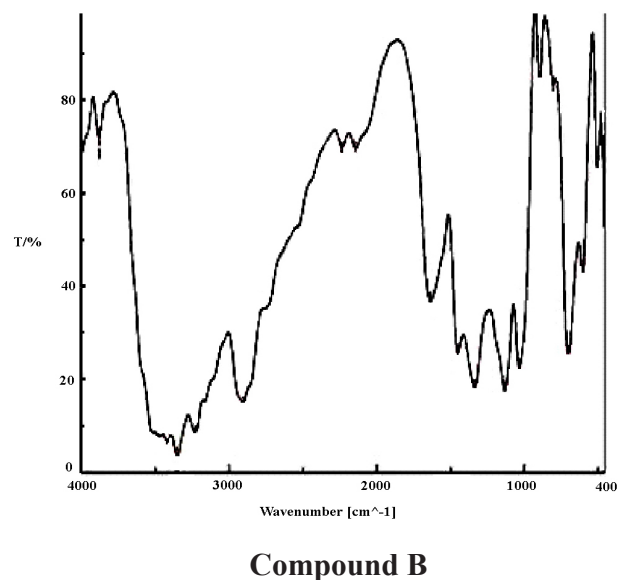

Fig. 1. FTIR compound $A$ : is $C M C$ and compound $\mathrm{B}$ : is CMC treated with nano zinc oxide

Egypt.J.Chem. 60, No. 4 (2017) 
$2906 \mathrm{~cm}^{-1}(\mathrm{C}-\mathrm{H}) ; 1634 \mathrm{~cm}^{-1}(\mathrm{C}=\mathrm{C}) ; 1450 \mathrm{~cm}^{-1}(\mathrm{C}-$ $\mathrm{O}) ; 503 \mathrm{~cm}^{-1}$ is characteristic for $\mathrm{Zn}-\mathrm{O}$ bond [30].

Transition electron microscope

Figure 2 (a-c) shows TEM images of nano zinc oxide prepared by the sol-gel method. They show that zinc oxide particle size is having an average range between $19-41 \mathrm{~nm}$. The Figure illustrates that, the size of nano zinc oxide increased when added $\mathrm{ZnO}$ by $3 \%$, while decreasing the

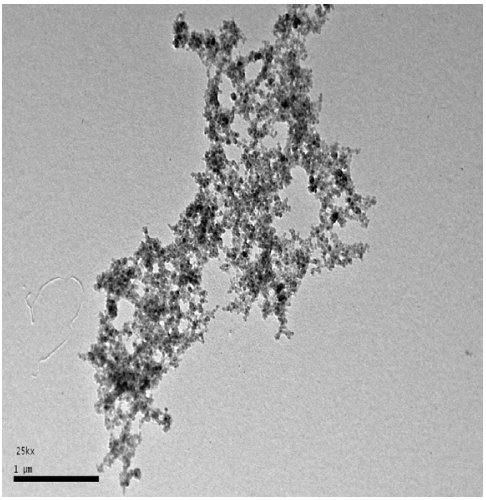

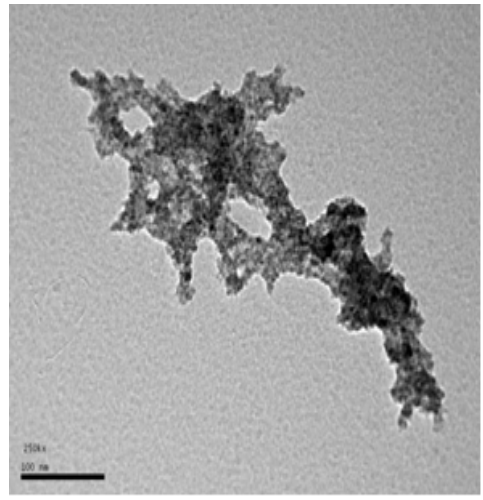

b

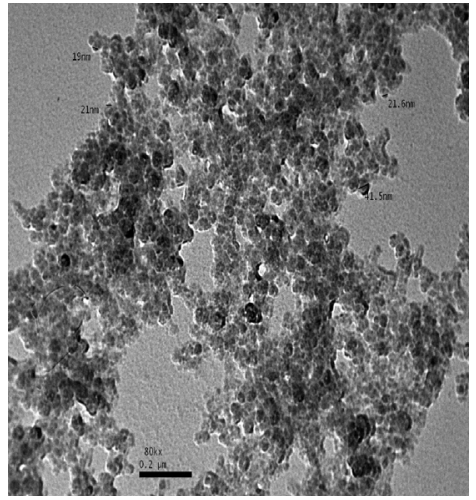

Fig. 2 (a-c). TEM image of nano zinc oxide particle with different particle size a; 19nm, b; 30nm, and c; with $40.5 \mathrm{~nm}$

concentration of the $\mathrm{ZnO}$ lead to incomplete growth of the $\mathrm{ZnO}$ nanoparticles.

\section{Scanning electron microscope}

The image as shown in Fig. 3 reflects the surface morphologies of carboxymethylated treated cotton fabrics with no observable difference. The images as shown in Fig. 3 (a-d) reflect the surface morphologies of

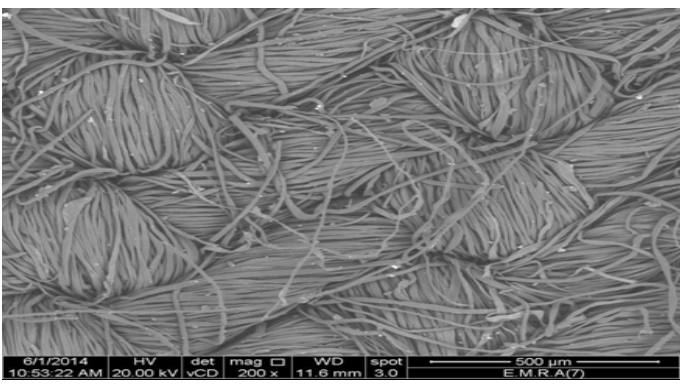

a

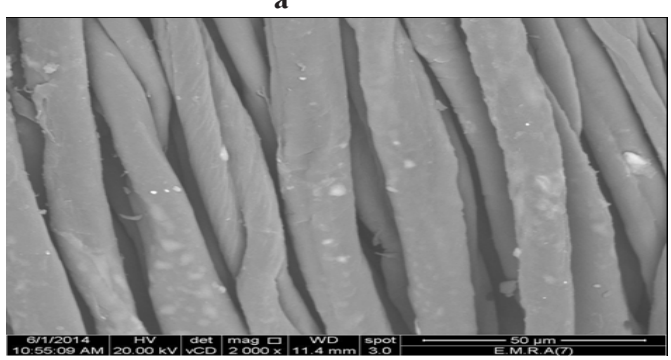

c carboxymethylated fabric treated with nano zinc oxide. Indeed, morphological imaging confirmed that the treated fabric was predominately covered by a layer. The Figure illustrates that the surface of the untreated specimen is comparably rough, but the treated specimen surface appears much smoother, in order to nano zinc oxide coating which leads to the flattening fiber surface. The SEM image confirmed that the size of nano zinc

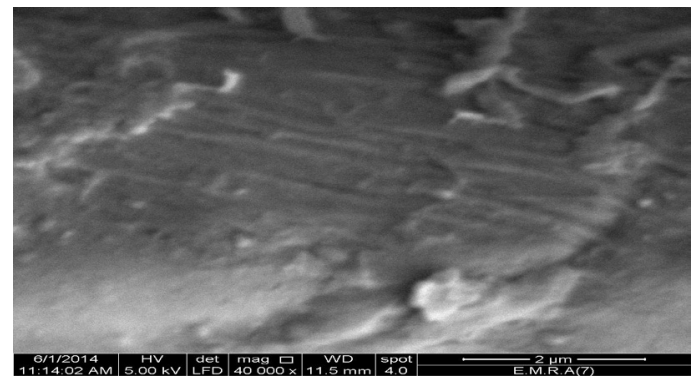

b

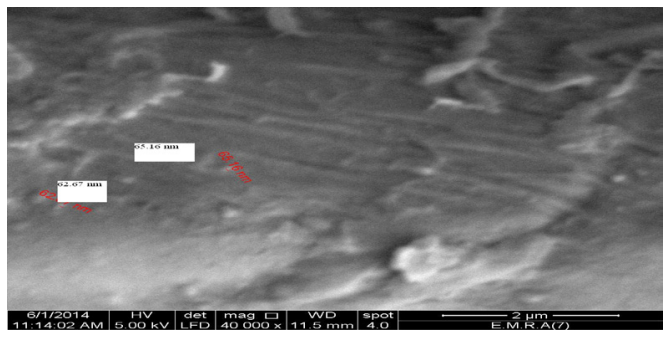

d

Fig. 3. SEM image of surface morphology of untreated cotton fabric (a-c), and carboxymethylated cotton fabric (d)

Egypt.J.Chem. 60, No.4 (2017) 
oxide particles existed in the surface was in the range of $62-65 \mathrm{~nm}$.

\section{UV-Visible}

Most of organic solvent (as; toluene) and water did not dissolve the zinc oxide powder (white crystalline). Hence UV-Visible spectra were recorded for the zinc oxide dispersed in methanol solution and also is represented in Fig. 4. The absorption band observed at $325 \mathrm{~nm}$ is the characteristic peak of zinc oxide nano material. The absorption peak is shifted to shorter wavelength compared to maximum absorption of zinc oxide occurs at $373 \mathrm{~nm}$. This shift is appropriate to the decrease in the size effect of nano structures. The approximate band gap value calculated from the $\lambda$ max value using the equation below [19].

Energy band gap $=1.2 / \lambda \max ^{(\mathrm{eV})}$

The band gap value is calculated from the above equation which is equal to $3.6 \mathrm{ev}$ which is characteristic for nano zinc oxide.

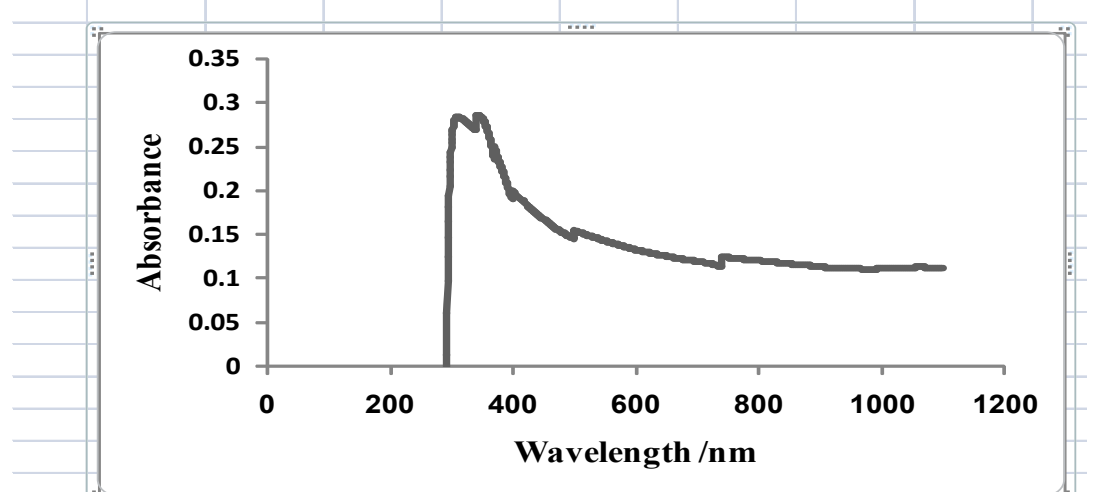

Fig. 4. UV-Visible curve of nano zinc oxide.

\section{$X$-ray diffraction}

Figure 5 depicts the X-ray diffraction (XRD) pattern of $\mathrm{ZnO}$ thin film deposited on the carboxymethylated treated cotton fabric. From the XRD pattern, one can clearly observe a diffraction peak at $2 \theta=34.78^{\circ}$. The strong preferential increase is observed along $\mathrm{C}$-axis, i.e. (002) plane indicating that the prepared $\mathrm{ZnO}$ nanocrystals have quartzite structure [31]. The unit cell "a" and "c" of the polycrystalline $\mathrm{ZnO}$ film with (002) orientation are calculated using the relation (3) and (4).

$$
\begin{aligned}
& \mathrm{c}=7 / \sin \theta \\
& \mathrm{c}=\lambda / \sin \theta
\end{aligned}
$$

The values obtained for the unit cell $\mathrm{a}=$ $2.59850 \AA$ and $c=4.50$ are in good agreement with those reported in the JCPDS standard data (Card no. 80-0074). Where $\lambda$, and $\theta$ are the X-ray wavelength $(=1.5406 \AA$ ), and Bragg angle respectively. Also, the XRD diffraction pattern shows three diffraction peaks at $2 \theta=15,16.5$ and 22.9.

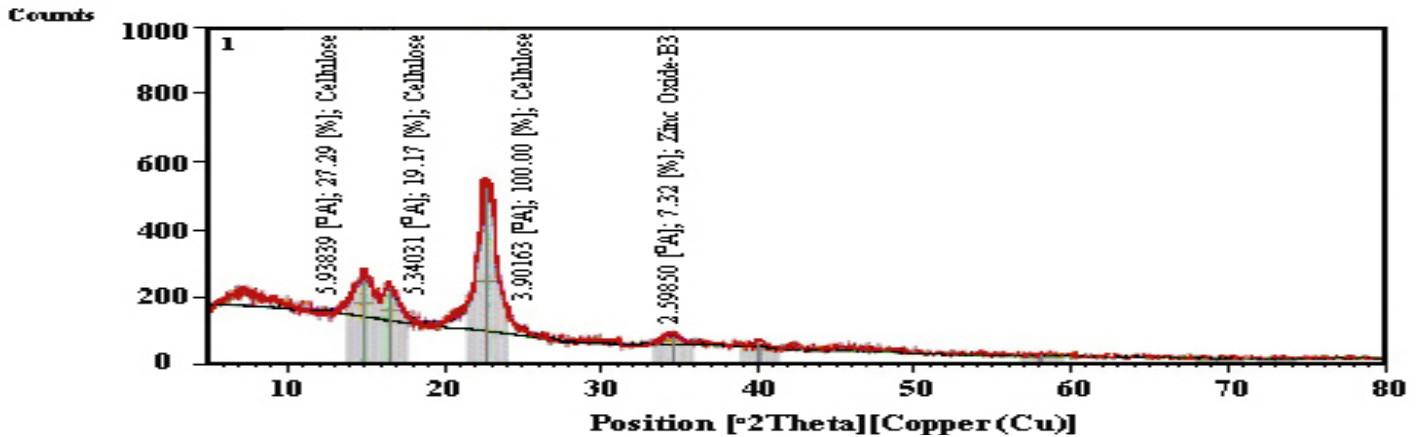

Fig. 5. XRD of CMC fabric treated with nano zinc oxide 
Flame retardancy mechanism for treating fabrictentative mechanism

In our paper, negative charge was located on the treated fabric as the carboxylate anion (COO-) by carboxymethylation of cotton fabric and subsequently extended to a layer of nano zinc oxide. Using citric acid, which works at SHP and cross-linker, which act as a catalyst to raise the percent of nano zinc oxide bonded to the cured fabrics as shown in Fig. 6 [32]

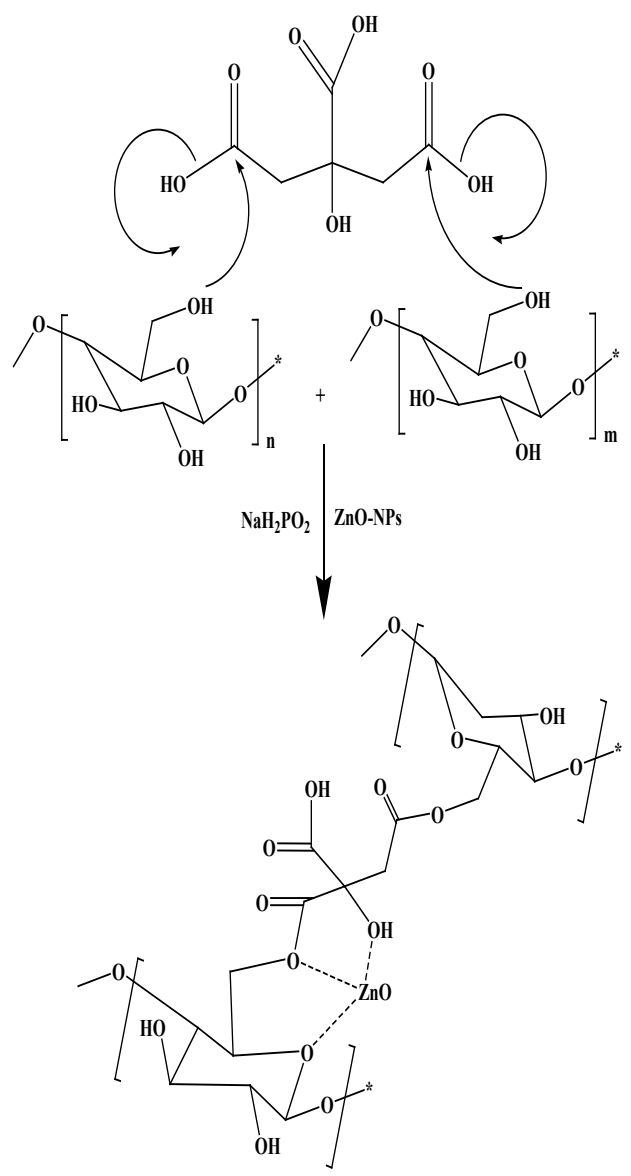

Fig. 6. Scheme mechanism between $\mathrm{CMC}$ with citric acid and nano zinc oxide

\section{Effect of citric acid concentration}

Table 1 illustrates that as the concentration of citric acid increased up to $4 \%$, the limiting oxygen index increased up to $23.7 \%$ and char residue up to $64.07 \%$ while, char length decrease to $3 \mathrm{~cm}$. By adding citric acid with the highest concentration $7 \%$ lead to decrease the percentage of oxygen to the lowest value $22.3 \%$ less than $4 \%$ concentration with the char length up to $4.5 \%$. These may be discussed that with further increasing the citric acid to $4 \%$ all active sites occupied, so no reaction between citric acid and nano zinc oxide occur and by washing the physically adsorbed nano zinc oxide and citric acid removed and decreased all the flammability properties.

Increasing the acid concentration (up to $7 \%$ ), decreases the tensile strength of the treated specimen to 50 and $18.0 \%$ for elongation. Finally, the whiteness recorded the highest value at cons. $4 \%$, then start to decrease as cons., increase recording the lowest value due to the fabric deteriorate.

\section{Effect of sodium hypophosphite}

SHP is a phosphorus-based salt working as a catalyst for cross-linking cellulose with polycarboxylic acids [33.34]. It has a direct effect on improving the performance properties of the treated fabric and catalyzing ester-crosslinking reactions, which consume the carboxyl groups and buffering the cross-linking system. The fabrics treated with SHP is due to increase bonding to the adjacent carbons in their molecular backbones and both are able to esterify cellulose by first forming a reactive 5 membered cyclic anhydride intermediate [35] as shown in Fig.1.

Table 2 shows that increase in the concentration of sodium hypophosphite lead to improving the flammability properties of the treated fabrics. As the concentration of SHP increased to 7\%, the LOI value increased to 25.5 and char residue increased gradually to $65.7 \%$, whereas char length decreased to $3.0 \mathrm{~cm}$. These may be discussed that increasing the concentration of SHP increases more bonding formed between nano zinc oxide, citric acid and carboxylic group on the treated fabrics were more nano zinc complex formed on the treated fabrics. The mechanical properties improved by inter chemical reaction, since the elongation decrease $(22.0 \%)$ the tensile strength increase (78.0Kg.f).

\section{Effect of nano zinc oxide concentration}

Table 3 illustrates the improvement in the ignition properties of the fabric, since adding nano zinc oxide with $3 \%$ concentration recording the highest oxygen index value $(25.8 \%)$, ash residue value $(69.2 \%)$ compared to the untreated specimen. $\mathrm{ZnO}$ nanoparticles have a direct effect of increasing the mechanical properties and whiteness index value $(79.0 \%)$, due to the interchemical reaction achieved between cotton fabric and nano particles of $\mathrm{ZnO}$. 
TABLE 1. Effect of citric acid concentration of the properties of fabrics coated by nano zinc oxide layer. Conditions used: Carboxylic content 335 meq/100gm cellulose, $3 \%$ nano zinc oxide, $6 \% \mathrm{SHP}$, dried at $85^{\circ} \mathrm{C}$ for $5 \mathrm{~min}$, curing at $160^{\circ} \mathrm{C}$ for $3 \mathrm{~min}$. The fabrics were evaluated after five washings

\begin{tabular}{|c|c|c|c|c|c|c|}
\hline $\begin{array}{c}\text { Concentration } \\
\text { citric acid } \\
/(\mathbf{\%})\end{array}$ & $\begin{array}{c}\text { LOI } \\
/(\mathbf{\%})\end{array}$ & $\begin{array}{c}\text { Char } \\
\text { length } \\
/(\mathbf{c m})\end{array}$ & $\begin{array}{c}\text { Char } \\
\text { residue } \\
/(\mathbf{\%})\end{array}$ & $\begin{array}{c}\text { Tensile } \\
\text { strength } \\
/(\mathbf{K g . f})\end{array}$ & $\begin{array}{c}\text { Elongation } \\
\text { at break } \\
/(\mathbf{\%})\end{array}$ & $\begin{array}{c}\text { Whiteness } \\
\text { index } \\
/(\%)\end{array}$ \\
\hline Untreated & 18.4 & 11.0 & 26.2 & 74.0 & 27.0 & 69.4 \\
\hline 3 & 22.8 & 3.8 & 62.8 & 80.0 & 22.0 & 71.0 \\
\hline 4 & 25.2 & 3.0 & 64.1 & 83.0 & 21.2 & 71.0 \\
\hline 5 & 22.8 & 3.4 & 63.3 & 75.0 & 20.0 & 66.0 \\
\hline 6 & 22.5 & 3.8 & 62.4 & 61.0 & 20.0 & 58.0 \\
\hline 7 & 22.3 & 4.5 & 58.2 & 50.0 & 18.0 & 54.0 \\
\hline
\end{tabular}

TABLE 2. Effect of sodium hypo phosphate concentration on the properties of fabrics coated by nano zinc oxide layer. Conditions used: Carboxylic content $335 \mathrm{meq} / \mathbf{1 0 0 g m}$ cellulose, $3 \%$ nano zinc oxide, $4 \%$ citric acid, dried at $85^{\circ} \mathrm{C}$ for $5 \mathrm{~min}$, curing at $160^{\circ} \mathrm{C}$ for $3 \mathrm{~min}$. The fabrics were evaluated after five washings

\begin{tabular}{|c|c|c|c|c|c|c|}
\hline $\begin{array}{c}\text { Concentration } \\
\text { SHP / (\%) }\end{array}$ & $\begin{array}{c}\text { LOI } \\
/ \mathbf{( \% )}\end{array}$ & $\begin{array}{c}\text { Char } \\
\text { length } \\
/(\mathbf{c m})\end{array}$ & $\begin{array}{c}\text { Char } \\
\text { residue } \\
/ \mathbf{( \% )}\end{array}$ & $\begin{array}{c}\text { Tensile } \\
\text { strength } \\
/ \mathbf{( K g . f )}\end{array}$ & $\begin{array}{c}\text { Elongation } \\
\text { at break } \\
/ \mathbf{( \% )}\end{array}$ & $\begin{array}{c}\text { Whiteness } \\
\text { index } \\
/(\mathbf{\%})\end{array}$ \\
\hline Untreated & 18.4 & 11.0 & 26.2 & 74.0 & 27.0 & 69.4 \\
\hline 4 & 21.9 & 4.7 & 61.3 & 79.0 & 22.0 & 71.0 \\
\hline 5 & 22.6 & 3.6 & 63.2 & 79.0 & 22.0 & 71.0 \\
\hline 6 & 25.2 & 3.0 & 64.1 & 83.0 & 21.2 & 71.0 \\
\hline 7 & 23.5 & 3.0 & 65.7 & 81.0 & 22.0 & 71.0 \\
\hline
\end{tabular}

TABLE 3. Effect of zinc oxide concentration on the flame retardancy and mechanical properties of fabrics. Conditions used: Carboxylic content $335 \mathrm{meq} / 100 \mathrm{gm}$ cellulose, $3 \%$ nano zinc oxide, $6 \% \mathrm{SHP}, 4 \%$ citric acid, dried at $85^{\circ} \mathrm{C}$ for $5 \mathrm{~min}$, curing at $160^{\circ} \mathrm{C}$ for $3 \mathrm{~min}$. The fabrics were evaluated after five washings

\begin{tabular}{|c|c|c|c|c|c|c|}
\hline $\begin{array}{c}\text { Concentration of } \\
\text { Zinc oxide } \\
/(\%)\end{array}$ & $\begin{array}{c}\text { LOI } \\
/(\%)\end{array}$ & $\begin{array}{c}\text { Char } \\
\text { length } \\
/(\mathbf{c m})\end{array}$ & $\begin{array}{c}\text { Char } \\
\text { residue } \\
/(\mathbf{\%})\end{array}$ & $\begin{array}{c}\text { Tensile } \\
\text { strength } \\
/(\mathbf{K g . f})\end{array}$ & $\begin{array}{c}\text { Elongation at } \\
\text { break } \\
/(\mathbf{\%})\end{array}$ & $\begin{array}{c}\text { Whiteness } \\
\text { index } \\
/(\mathbf{\%})\end{array}$ \\
\hline Untreated & 18.4 & 11.0 & 26.2 & 74.0 & 27.0 & 69.4 \\
\hline 3 & 25.2 & 3.0 & 64.1 & 83.0 & 21.2 & 71.0 \\
\hline 4 & 23.2 & 3.0 & 61.3 & 82.6 & 22.0 & 73.0 \\
\hline 5 & 22.9 & 3.1 & 58.9 & 82.0 & 23.0 & 75.3 \\
\hline 6 & 22.3 & 3.3 & 58.6 & 80.0 & 23.5 & 74.0 \\
\hline
\end{tabular}

Effect of curing temperature

Table 4 shows that increasing the curing temperature from 150 to $160 \circ \mathrm{C}$ increase the oxygen index value up to $25.2 \%$ and char residue increase gradually up to $64.1 \%$ with char length decreasing $73 \%$ compared to the untreated specimen. Increasing the curing temperature lead to form more nano zinc oxide and more complex of nano zinc oxide with citric acid to act as a thermal barrier layer to the treated fabrics. With further increase the curing temperature up to $180^{\circ} \mathrm{C}$ has a bad effect on the flammability properties as the 
limiting oxygen index value decreased to $22.0 \%$ and char residue also decreased to $50.4 \%$. These may discuss in that at higher curing temperature there were unsaturated acids formed which decreases the bonding between citric acid and carboxymethylated treated fabrics. Moreover,
Table 4 shows that as the curing temperature increases up to $180^{\circ} \mathrm{C}$, the tensile strength decreased to 61.0 and whiteness index also decreased to 51.0 may due to discoloration and formation of unsaturated acid.

TABLE 4. Effect of curing temperature on the flame retardancy and physical properties of treated cotton fabrics. Conditions used: Carboxylic content $335 \mathrm{meq} / 100 \mathrm{gm}$ cellulose, $3 \%$ nano zinc oxide, $6 \% \mathrm{SHP}, 4 \%$ citric acid, dried at $85^{\circ} \mathrm{C}$ for $5 \mathrm{~min}$, cured for $3 \mathrm{~min}$ at $160^{\circ} \mathrm{C}$. The fabrics were evaluated after five washings

\begin{tabular}{|c|c|c|c|c|c|c|}
\hline $\begin{array}{c}\text { Curing } \\
\text { temperature } /{ }^{\circ} \mathbf{C}\end{array}$ & $\begin{array}{c}\text { LOI } \\
/(\mathbf{( \% )}\end{array}$ & $\begin{array}{c}\text { Char } \\
\text { length } \\
/(\mathbf{c m})\end{array}$ & $\begin{array}{c}\text { Char } \\
\text { residue } \\
/ \mathbf{( \% )}\end{array}$ & $\begin{array}{c}\text { Tensile } \\
\text { strength } \\
/(\mathbf{K g . f})\end{array}$ & $\begin{array}{c}\text { Elongation at } \\
\text { break } \\
/(\%)\end{array}$ & $\begin{array}{c}\text { Whiteness } \\
\text { index } \\
/(\mathbf{\%})\end{array}$ \\
\hline Untreated & 18.4 & 11.0 & 26.2 & 74.0 & 27.0 & 69.4 \\
\hline 150 & 22.0 & 4.9 & 58.0 & 79.0 & 25.0 & 71.0 \\
\hline 160 & 25.2 & 3.0 & 64.1 & 83.0 & 21.2 & 71.0 \\
\hline 170 & 23.0 & 5.0 & 58.3 & 72.0 & 20.0 & 62.0 \\
\hline 180 & 22.0 & 5.4 & 50.4 & 61.0 & 18.0 & 51.0 \\
\hline
\end{tabular}

\section{Effect of curing time}

The curing time has a direct effect on increasing the value of LOI. Table 5 shows that increasing curing time from 1 up to $3 \mathrm{~min}$, the value of oxygen index increased to $19.3 \%$ and $23.7 \%$, respectively, the char residue up to $64.1 \%$ from the weight test, while the char length decreased to $2.8 \mathrm{~cm}$ (at curing time $3 \mathrm{~min}$ ). With further increased, the curing time up to $7 \mathrm{~min}$ the LOI has a slight decrease and reached $23.3 \%$, while char length $7.6 \mathrm{~cm}$. These may be explained that at curing time $3 \mathrm{~min}$, the more increase in the formation of nano zinc oxide, which imparts thermal barrier layer to the treated fabrics. Increasing the curing time has a negative effect on the tensile strength, elongation and whiteness index.

TABLE 5. Effect of curing time on the flame retardancy and physical properties of treated cotton fabrics. Conditions used: Carboxylic content 335 meq/100gm cellulose, $3 \%$ nano zinc oxide, $6 \%$ SHP, $4 \%$ citric acid, dried at $85^{\circ} \mathrm{C}$ for $5 \mathrm{~min}$, cured for $3 \mathrm{~min}$ at $160^{\circ} \mathrm{C}$. The fabrics were evaluated after five washings

\begin{tabular}{|c|c|c|c|c|c|c|}
\hline $\begin{array}{c}\text { Curing time } \\
/ \mathbf{m i n}\end{array}$ & $\begin{array}{c}\text { LOI } \\
/(\mathbf{\%})\end{array}$ & $\begin{array}{c}\text { Char } \\
\text { length } \\
/(\mathbf{c m})\end{array}$ & $\begin{array}{c}\text { Char } \\
\text { residue } \\
/(\mathbf{\%})\end{array}$ & $\begin{array}{c}\text { Tensile } \\
\text { strength } \\
/(\mathbf{K g . f})\end{array}$ & $\begin{array}{c}\text { Elongation at } \\
\text { break } \\
/(\mathbf{\%})\end{array}$ & $\begin{array}{c}\text { Whiteness } \\
\text { index } \\
/(\mathbf{\%})\end{array}$ \\
\hline Untreated & 18.4 & 11.0 & 26.2 & 74.0 & 27.0 & 69.4 \\
\hline 1 & 22.8 & 5.7 & 63.9 & 82.0 & 23.0 & 71.0 \\
\hline 3 & 25.2 & 3.0 & 64.1 & 83.0 & 21.2 & 71.0 \\
\hline 5 & 23.8 & 4.8 & 64.2 & 65.0 & 17.0 & 57.0 \\
\hline 7 & 23.3 & 7.6 & 64.3 & 55.0 & 16.0 & 51.0 \\
\hline
\end{tabular}

\section{Conclusions}

Applying layer by layer (LbL) assembly technique for improving the flame retardant properties of cotton fabric without serious damage in the mechanical properties is our achievement in this work. The carboxymethylated cotton fabric having carboxyl content $335 \mathrm{meq} / 100 \mathrm{gm}$ cellulose was treated with nano-ZnO (3-6\%) and different treatment condition of curing time and temperature as well as, citric acid and SHP get an adequate balance between greatest flame retardant properties (represented as a highest LOI value) and lest deterioration of fabric mechanical 
properties (expressed as; tensile strength and elongation percentage). Optimum flame retardant properties $(25.3 \%$ LOI) with lowest mechanical deterioration were obtained with the following conditions carboxylic content $335 \mathrm{meq} / 100 \mathrm{gm}$ cellulose, $3 \%$ nano zinc oxide, $6 \%$ SHP, $4 \%$ citric acid, dried at $85 \mathrm{oC}$ for $5 \mathrm{~min}$, cured for $3 \mathrm{~min}$ at $160 \mathrm{oC}$. The fabrics were evaluated after five washings. The obtained data were proved using SEM and XRD.

\section{Acknowledgements}

The Authors wish to thank Porf. Dr. M. A. Nour, Chairman of Chemistry Division, Prof. Dr. Ferial M. Tera and Prof. Dr. Monira Michael, Textile Metrology, Chemistry Division, National Institute for Standards (NIS), Ministry of Higher Education and Scientific Research, Egypt for their suppor and help by revision and guiding me to finish this manuscript.

\section{References}

1. Gashti, M.P., Elahi, A. and Gashti, M.P., UV radiation inducing succinic acid/silica-kaolinite network on cellulose fiber to improve the functionality. Comp. Part B: Eng. 48, 158 (2013)

2. Brown, P.J. and Stevens, K., Nanofibers and Nanotechnology in Textiles. Cambridge (UK): Woodhead Publishing, (2007)

3. Caldara, M., Colleoni, C., Guido, E., Re, V. and Rosace, G., Development of a textile optoelectronic $\mathrm{pH}$ meter based on hybrid xerogel doped with methyl red. Sens. Actuat. B Chem. 171, 1013 (2012)

4. Colleoni, C., Massafra, M.R. and Rosace, G., Photocatalytic properties and optical characterization of cotton fabric coated via sol-gel with noncrystalline $\mathrm{TiO} 2$ modified with poly(ethylene glycol). Surf. Coat. Technol. 207, 79 (2012)

5. Gulrajani, M.L. and Gupta, D., Emerging techniques for functional finishing of textiles. Ind. J. Fibre Text. Res. 36, 388 (2011)

6. Yu, H., Chen, G.Y., Yao, J. and Wang, Y., A facile one-pot route for preparing cellulose nanocrystal/ zinc oxide nanohybrids with high antibacterial and photocatalytic activity, Cellulose, 22 (1), 261 (2015)
7. Abd El-Hady, M., Farouk, A. and Sharaf, S., Flame retardancy and UV protection of cotton based fabrics using nano- $\mathrm{ZnO}$ and polycarboxylic acids, Carb. Pol. 92, 400 (2013)

8. Lam, Y.L., Kan, C.W. and Yuen, C.W.M., Effect of Titanium Dioxide on the Flame-Retardant Finishing of Cotton Fabric. Appl. Polym. Sci. 121 (1), 267 (2011)

9. Alongi, J., Colleoni, C., Rosace, G. and Malucelli, G., Phosphorus- and nitrogen-doped silica coatings for enhancing the flame retardancy of cotton: Synergisms or additive effects? Poly. Deg. Stab. 98, 579 (2013)

10. Decher, G. and Schlenoff, J.B., Multilayer thin films: Sequential assembly of nano composite materials. Weinheim (Germany): Wiley VCH, 543 (2002)

11. Malucelli, M., Surface-Engineered Fire Protective Coatings for Fabrics through Sol-Gel and Layerby-Layer Methods: An Overview. Coatings, 6, 33 (2016)

12. Shimazaki, Y., Mitsuishi, M., Ito, S. and Yamamoto, M., Preparation and Characterization of the Layerby-Layer Deposited Ultrathin Film Based on the Charge-Transfer Interaction in Organic Solvents. Langmuir, 14, 2768 (1998)

13. Wang, X., Naka, K., Wang, C., Itoh, H., Uemura, T. and Chujo, Y., Layer-by-Layer Films Based on Charge Transfer Interaction of Conjugated Poly (dithiafulvene) and Incorporation of Gold Nanoparticles into the Films. Appl. Polym. Sci. 103, 1608 (2007)

14. Jang, W.S., Rawson, I. and Grunlan, J.C., Layerby-layer assembly of thin film oxygen barrier. Thin Sol. Films, 516, 4819 (2008)

15. Decher, G. and Hong, J.D., Buildup of ultrathin multilayer films by a self-assembly process, 1 consecutive adsorption of anionic and cationic bipolar amphiphiles on charged surfaces. Makromol. Chem. Macromol. Symp. 46, 321 (1991)

16.Bernt, P. and Kurihara, K., Adsorption of poly(styrenesulfonate) onto an ammonium monolayer on mica: A surface forces study. Langmuir. 8(10), 2486 (1992) 
17. Carosio, F., Alongi, J., Frache, A., Malucelli, G. and Camino, G., In: Morgan A.B., Nelson G.L., Wilkie C.A. (Ed.) Fire and polymers VI: new advances in flame retardant chemistry and science. Washington DC (USA): ACS Symposium Series, 1118, Chapter $22(2012)$

18. Alongi, J. and Malucelli, G., Thermal stability, flame retardancy and abrasion resistance of cotton and cotton-linen blends treated by sol-gel silica coatings containing alumina micro- or nanoparticles. Polym. Degrad. Stab. 98 (8), 1428 (2013)

19. Yadav, A., Prasad, V.A., Kathe, A.A., Raj, S., Yadav, D. and Sundaramoorthy, C., Functional finishing in cotton fabrics using zinc oxide nanoparticles. Bull. Mat. Sci. 29, 641 (2006)

20. Yi, S.H., Choi, S.K., Jang, J.M., Kim, J.A. and Jung, W.G., Low-temperature growth of $\mathrm{ZnO}$ nanorods by chemical bath deposition. Coll. Int. Sci. 313, 705 (2007)

21. Hashem, M., Refaie, R. and Hebeish, A., Crosslinking of partially carboxymethylated cottonfabric via cationization. Clean. Prod. 13, 947 (2005)

22. ISO 4589: Determination of flammability by oxygen index, pp. 12-15 (1984)

23. BS 3119: Specification for method of test for flame proof materials (textile). British Standard Institution, London (1959)

24. Gaan, S., Sun, G., Hutches, K. and Engelhard, M.H., Effect of nitrogen additives on flame retardant action of tributyl phosphate: Phosphorusnitrogen synergism. Polym. Degrad. Stab. 39 (1), 99 (2008)

25. ASTM D 5035-06: Standard Test Method for Breaking Force and Elongation of Textile Fabrics, (2008)

26.AATCC Test Method 135-1985: Colour measurement of textiles', Technical manual of the AATCC, Research Triangle Path, USA, 2003.

27. Barbara, H., Infrared Spectroscopy: Fundamentals and Application, John Wiley \& Sons. Ltd., Southern Gate, Chichester, England, 2005.

28. Younis A.A., Nour M.A. and El-Nagar Kh., Egypt.J.Chem. 60, No.4 (2017)
Studying the Effect of Phosphorylated Sol-Gel on Polyester Fabric as FlameRetardant Coating. Appl. Chem. 70, 24230 (2017).

29. Rahman, M.A.A., Mahmud, S., Alias, A. and Nor, A.F.M., Effect of Nanorod Zinc Oxide on Electrical and Optical Properties of Starch-based Polymer Nanocomposites. Phy. Sci. 24 (1), 17 (2013).

30. Kleinwechter, H., Janzen, C., Knipping, J., Wiggers, H. and Roth, P., Formation and properties of $\mathrm{ZnO}$ nano-particles from gas phase synthesis processes. Mater. Sci. 37, 4349 (2002).

31. Sivakumar, A., Sundaresan, K., Murugan, R. and Periyasamy, S., UV protection and selfcleaning finish for cotton fabric using metal oxide nanoparticle. Indi. J. Fib. Text. Res. 38 (3), 285 (2013)

32. Mohamed, Fatma A., Ibrahim, H. M., El-Kharadly, Elham A. and El-Alfy. Ekhlas A., Improving Dye ability and antimicrobial properties of Cotton Fabric. App. Phar. Sci. 6(02), 119 (2016).

33. $\mathrm{Wu}, \mathrm{X}$. and Yang, C.Q., Flame retardant finishing of cotton fleece fabric. II Inorganic phosphorus containing compounds. Appl. Polym. Sci. 108, 1582 (2008).

34. Yang, CQ., FT-IR Spectroscopy study of the catalysis for ester cross linking of cotton cellulose catalyzed by sodium hypophosphite. Text. Res. J. 171, 201 (2001)

35. Yang, CQ, Wang, XL and Kang, IS., Ester crosslinking of cotton fabric by polymeric carboxylic acids and citric acid. Text. Res. J. 67, 334 (1997). 


\section{مثبت لهب صديق للبيئة عن طريق التجميع الذاتى للطلاء}

إخلاص الالفى ، أحمد عابدين محمد يونس ، سماحة سيد حسين و أحمد سلامة

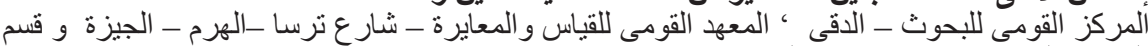

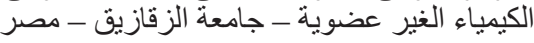

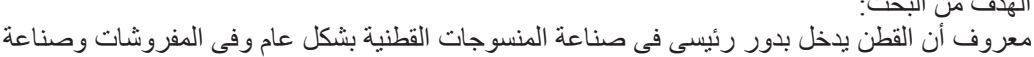

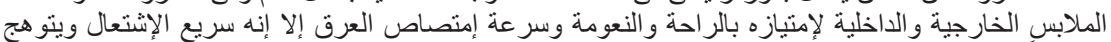

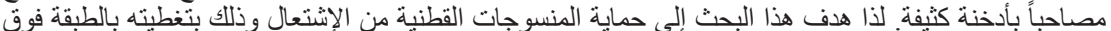

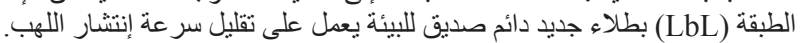

كما تناول هذا البحث إلى إختبار أفضل ظروف المعالجة من حيث ثركيز حمض الستريك و الصوديوم هيبوفوسفات

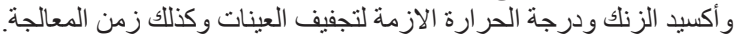

$$
\text { قياس المحتوى الإخبار اتكربو كسيلى لعينات القطن المختبرة. }
$$

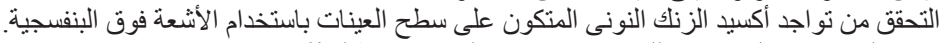

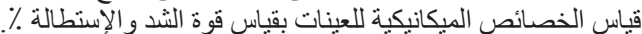

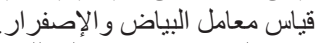

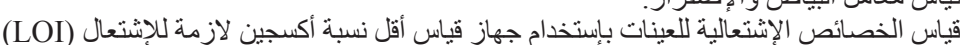

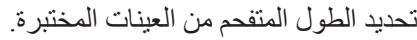
قياس نسبة الوزن المتفحم الناتج من العينات.

أكد تحلل العينات بإستخدام FTIR وجود المجمو عات الحديثة التى تم تغطية سطح العينات القطنية المعالجة أكد فحص العينات عن طريق TEM وجود جزيئات ZnO فى مستوى النانوى بأحجام جزيئات تثر اوح بين

أثثبت المسح الإلكترونى الميكروسكوبى (SEM) أن سطح العينات المعالجة أكثر إستواء ونعومة وذلك يؤكد وجود ZnO

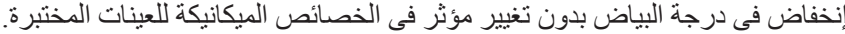

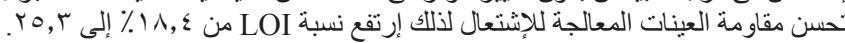

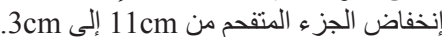
تُ التوصل لأفضل ظروف التف المعالجة للعينات للحصول على أفضل مقاومة للإشتعال وكانت كالتالى:

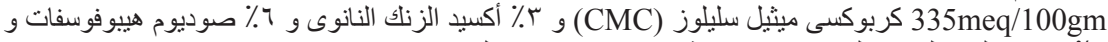

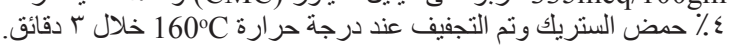

